Pamiętnik Literacki 2020, 2, s. 203-212

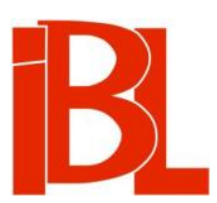

\title{
Jeszcze jeden przyczynek do recepcji twórczości Sannazara w literaturze staropolskiej
}

Roman Mazurkiewicz 
Pamiętnik Literacki CXI, 2020, z. 2, PL ISSN 0031-0514

DOI: $10.18318 / \mathrm{pl} .2020 .2 .16$

ROMAN MAZURKIEWICZ Uniwersytet Pedagogiczny, Kraków

\section{JESZCZE JEDEN PRZYCZYNEK DO RECEPCJI TWÓRCZOŚCI SANNAZARA W LITERATURZE STAROPOLSKIEJ}

Przygotowując z Elwira Buszewicz do wydania poemat Grzegorza Czaradzkiego Rytmy o porodzeniu przenaczystszym Bogarodzice Panny Maryjej (1613) ${ }^{1}$, który okazał się nie zidentyfikowanym wcześniej przekładem De partu Virginis (1526) Jacopa Sannazara ${ }^{2}$, w aneksie tej edycji zebraliśmy znane już przedtem oraz odnalezione w trakcie bieżących kwerend literackie świadectwa recepcji twórczości „chrześcijańskiego Wergiliusza” w dawnej Polsce. Były to m.in. utwory Hieronima Morsztyna, Szymona Zimorowica, Mikołaja Grodzińskiego, Jana Gawińskiego, Jana Aleksandra Koreywy, Samuela Przypkowskiego, Jakuba Teodora Trembeckiego, Józefa Andrzeja Załuskiego, Benedykta Chmielowskiego, Ignacego Krasickiego. Zdając sobie sprawę z niekompletności tego rejestru, wyrażaliśmy przeświadczenie, że „Dalsze studia w tym zakresie ujawnią zapewne niejeden jeszcze staropolski utwór wprost lub pośrednio inspirowany dziełami neapolitańskiego humanisty"3. A, jak powszechnie wiadomo, najciemniej bywa pod latarnią, jeśli w tym przypadku jako mimowolną wskazówkę potraktować przywołane we wstępie do edycji Rytmów emfatyczne pytanie Jana Czubka:

Więc ani wiek Grochowskiego, ani czasy Kochowskich i Potockich nie wydały miłośnika i znawcy chrześcijańskiej poezyi Sannazara, posiadającego na tyle kunszt poetycki, żeby ją dał poznać w ojczystym rymie rodakom? ${ }^{4}$

Wśród uwzględnionych we wspomnianym aneksie rodzimych „naśladowców” Sannazara zabrakło pierwszego z wymienionych - Stanisława Grochowskiego. A to

$1 \quad$ G. C z a ra d z ki, Rytmy o porodzeniu przenaczystszym Bogarodzice Panny Maryjej. Wyd. i oprac. R. Mazurkiewicz, E. Buszewicz. Red. nauk. A. Nowicka-Jeżowa, R. Mazurkiewi c z. Warszawa 2009.

2 Zob. R. Mazurkiewi c z, O przeoczonym staropolskim przekładzie „De partu Virginis” Jacopa Sannazara, W zb.: Rzeczy minionych pamięć. Studia dedykowane Profesorowi Tadeuszowi Ulewiczowi w 90. rocznicę urodzin. Red. A. B or ow ski, J. Niedźwi e dź. Kraków 2007.

$3 \quad Z$ literackiej recepcji Sannazara $w$ dawnej Polsce. W: C z a r a d z k i, op. cit., s. 218. Przewidywanie to spełniło się dość szybko - zob. D. D y b e k, Jeszcze jeden dowód na znajomość „De Partu Virginis” Jacopa Sannazara w Polsce (?). W zb.: Przechadzki po lesie teorii i nie tylko. Szkice o literaturze, języku i kulturze. Prace ofiarowane prof. dr. hab. Wojciechowi Solińskiemu na siedemdziesiate urodziny. Red. M. Tarnogórska, K. Lis ow ska. Wrocław 2019.

4 R. Mazurkiewicz, E. Buszewicz, wstęp w: Czaradzki, op. cit., s. 8. - J. Czubek, Ślad Sannazara $w$ Polsce. „Pamiętnik Literacki” 1910, z. 1/4, s. 533. 
właśnie on winien się znaleźć w naszym zestawieniu na samym jego początku, nie tylko ze względu na chronologię.

W roku 1611 krakowska oficyna Bazylego Skalskiego wypuściła niewielki, liczacy zaledwie 12 kart, druczek Grochowskiego Cudowne wiersze $z$ indyjskiego języka przełożone, albo Żałoba Panny Naświętszej o męce Pana Jezusa, syna jej, $z$ krótka o tymże historyją. Przydane są do tego niektore insze rytmy tejże materyjej służace $e^{5}$. Tytuł ten, zwłaszcza w odnotowanym przez Estreichera drugim jego wariancie $^{6}$, jest nie tylko frapujący, ale i niezbyt jasny, zwłaszcza dla dzisiejszego czytelnika. Sformułowanie „Cudowne wiersze $z$ indyjskiego języka przełożone” odnosi się bowiem do jednego tylko utworu, mianowiecie łacińskiego „Pater en noster, genitor noster...”, który został określony w żywej paginie druku jako „Wiersze albo pieśń o Męce Pańskiej” (tu „wiersze” w znaczeniu “wersy’) i uznany przez ks. Grochowskiego za pierwszą „żałobę Panny Naświętszej”. Drugim planktem Maryi, nie należącym już jednak do „cudownych wierszy” (w znaczeniu 'objawionych w cudowny sposób'), jest tekst „Ah, mater, iam non mater...”. Stempla cudowności nie posiadają również pozostałe utwory, których w zbiorku Grochowskiego jest kilkanaście:

s. 2: wiersz dedykacyjny „Jaśnie Wielmożnemu Panu, Jego Miłości Panu Kasprowi Maciejowskiemu [...]”;

s. 3-4: polski przekład wiersza „Z Franciszka Benciusa” („Oto przybity do krzyża srogiego...”);

s. 4-5: Tekst łaciński tejże pieśni od Franciszka Benciusa przełożony („Pater en noster, genitor noster...");

s. 5-7: Druga żałoba Panny Naświętszej [...] („Ach, matko, już nie matko...”);

s. 7-8: Też wiersze po łacinie („Ah, mater, iam non mater...”);

s. 9-11: Trzeci wiersz takiejże materyjej („Wszyscy mieszkańcy domu niebieskiego...");

s. 11-14: Tekst łaciński tegoż sensu („Aetheris alti plangite cives...”);

s. 15-17: Żałosne niewiasty albo narzekalnice [...]:

Pierwszej lament („Przed kim się mamy skarżyć...”);

II. „Proroku miłosierny...”;

III. „Zeszłaby się mej głowie woda...”;

IV. „Śliczny kwiatku panieński...”;

V. „Dobrodzieju potrzebnych...”;

s. 18-22: Serdeczne narzekanie przy grobie Pańskim błogosławionej Maryjej Magdaleny („W pierwszy dzień po sobocie...”);

s. 23-24: Porankowa i wieczorna do skruchy zaprawa na ksztatt modlitwy.

5 S. G r o c how s ki, Cudowne wiersze z indyjskiego języka przełożone, albo Żałoba Panny Naświętszej o męce Pana Jezusa, syna jej, z krótką o tymże historyja. Przydane są do tego niektore insze rytmy tejże materyjej służące, Kraków 1611. Pierwsza część tego tytułu została powtórzona na s. 3 druku, jako nagłówek wiersza „Pater en noster, genitor noster...”.

$6 \quad$ Według Estreichera (Bibliografia polska. T. 17. Kraków 1899, s. 376) były dwa warianty strony tytułowej Cudownych wierszy; w drugim z nich tytuł brzmiał następująco: Cudowne wiersze $z$ indyjskiego języka na łacińskie przez Franciszka Bencyjusza, a teraz z łacińskiego na polski przełożone, albo żałoba Panny Naświętszej o męce Pana Jezusa, syna jej, z krótka o tymże historyja. Przydane są do tego niektóre insze rytmy tejże materyjej służace. 
Największym zainteresowaniem badaczy cieszył się dotychczas łaciński wiersz włoskiego jezuity Franciszka Bencjusza „Pater en noster, genitor noster...” oraz jego przekład pióra Grochowskiego („Oto przybity do krzyża srogiego...”) ${ }^{7}$. Niezwykłe okoliczności powstania tego tekstu, a właściwie cudownego objawienia go przez Matkę Bożą, opisuje Grochowski w „krótkiej o temże historyjej”:

W prowincyjej Kollao jest jedno miasto, które zową Kapakabano, kędy widać obraz jeden Naświętszej Panny sławny, miedzy któremi ten przedniejszy i wielą cudów słynący. Jeden człowiek rodem z Indyjej tak spuchłe miał nogi, iż nie mógł postapić na nich. Tego Naświętsza Panna nauczyła przez sen abo też na jawi pieśni jednej nabożnej o męce Syna swego, którą potym Franciszek Bencius przetłumaczył na wiersze łacińskie, a teraz polskim językiem wydana ${ }^{8}$.

Zarówno tytuł zbiorku Grochowskiego, jak i przytoczona tu „historyja” stały się kanwą ciągnącego się przez dziesięciolecia „orientalistycznego nieporozumienia”: Cudowne wiersze $\mathrm{z}$ indyjskiego języka przełożone uznano za świadectwo zainteresowań w dawnej Polsce Dalekim Wschodem, pieśń zaś przetłumaczoną na łacinę przez Bencjusza, a potem spolszczona przez Grochowskiego - za utwór napisany pierwotnie „w którymś z narzeczy indyjskich”. Mało tego, nawet w poważnych opracowaniach wciąż powielana jest bałamutna informacja, jakoby „pierwszym utworem sanskryckim tłumaczonym na język polski była przełożona przez Grochowskiego (za Bencjuszem) Bhagawadgita, jako Cudowne wiersze $z$ indyjskiego (1611)"10. I to mimo faktu, że już w 1984 roku ukazał się zwięzły, ale przełomowy w tym zakresie artykuł Mieczysława Mejora, w którym badacz opublikował przypuszczalne źródło „indyjskiej historii” - sporządzone przez o. Franciszka Bencjusza sprawozdanie Towarzystwa Jezusowego $z$ roku 1589, gdzie znalazły się m.in. doniesienie o cudownym uzdrowieniu cierpiącego na opuchliznę nóg mieszkańca dalekiego Peru oraz łaciński przekład pieśni o męce Chrystusa, przekazanej mu we śnie przez Matkę Bożą. Mejor konkluduje:

Orientalistyczne nieporozumienie wynika [...] z faktu opacznego zrozumienia łacińskiego przymiotnika Indicus, jaki występuje we wstępie do Cudownych wierszy (,.verba... descripta sunt Indica lingua”). [...] Tak oto przez filologiczną nieścisłość z „historii peruwiańskiej” otrzymaliśmy „historię z życia katolików indyjskich" i jeszcze jeden przykład zainteresowań Indiami u dawnych Polaków. Ks. Stanisław Grochowski wprowadził tym samym w błąd (nieświadomie!) późniejszych orientalistów ${ }^{11}$.

Autor Cudownych wierszy, jak słusznie zauważa Mejor, nie musiał mieć w rę-

Incipit polskiego tłumaczenia tej pieśni znajduje się w rękopiśmiennym kancjonale benedyktynek sandomierskich $z$ poczatku XIX wieku.

8 Grochowski, op. cit., s. 3.

9 Zob. B. B a r a n ow s k i, Znajomość Wschodu w dawnej Polsce do XVIII wieku. Łódź 1950, s. 225. J. Tu czyńs ki, Motywy indyjskie w literaturze polskiej. Warszawa 1981, s. 28-29.

10 J. Krzyża now ski, Orient. Indie. W zb.: Literatura polska. Przewodnik encyklopedyczny. Red. ... T. 2. Warszawa 1984, s. 96. Zob. też L. Su dy k a, Translations and Adaptations of Rāmāyaṇa in Poland. W zb.: Indian Epic Values: Rāmāyaṇa and Its Impact. Ed. G. Polle t. Leuven 1995, s. 89. - Literatura polska XX wieku. Przewodnik encyklopedyczny. Red. nauk. A. H u tn i ki e w i c z, A. La m. T. 2. Warszawa 2000, s. 502. - J. Szy m a ń s ka, Polscy wydawcy przekładów z literatur orientalnych $w$ XX wieku. Warszawa 2000, s. 23.

11 M. M ej or, Orientalistyczne nieporozumienie. „Meander” 39 (1984), nr 7/8, 374-375. Ustalenia Mejora uwzględnił ostatnio R. Krzywy w opracowanej przez siebie edycji: S. Grochowski, Toruńskie nocy. Warszawa 2017, s. 17. 
kach sprawozdania Bencjusza, a wiadomość o niezwykłym zdarzeniu „w Indyjej” oraz utwór „Pater en noster, genitor noster...” otrzymał zapewne od Kaspra Maciejowskiego, kasztelana lubelskiego, któremu przypisał swój zbiorek ${ }^{12}$. O okolicznościach jego powstania wspomina ks. Grochowski w wierszu dedykacyjnym, w którym stary już i schorowany poeta snuje refleksje o atmosferze religijnej początku XVII stulecia:

Acz po inszych rzeczach znać, zacny kasztelanie,
Że rozkosz twoja myślić o Chrystusie Panie,
Jednak i ten u mnie znak niemały jest tego,
Że na sercu uważasz srogą mękę jego,
Przez którą nas Zbawiciel i z Ojcem pojednał
I żywot nieśmiertelny w chwale swojej zjednał.
Bo wierzę, nie skądinąd wzięła cię ochota,
Że te wiersze cudowne, droższe wszego złota,
Chciałeś mieć w język polski przez mię przełożone,
O czym świadczą dwa listy do mnie przyniesione.
Zdziwiłem się twej chęci w tej mierze gorącej,
Już od roku i dawniej tych rzeczy pragnącej,
Kto bowiem, ile świecki, tym się teraz para,
Kto nie raczej o ten świat nikczemny się stara?
Trudnoć to było na mię, ile schorzałego,
Z pismem trudnym biedzić sie języka obcego,
Ale zaś Maciejowski, patrząc z drugiej strony,
Jaka dziś Kościół Boży chęcią zapalony
Uważa Męki Pańskiej drogie tajemnice,
Tak, iż ni o czym inszym brzmią wiernych świątnice,
Próżnom się miał sprzeciwić, ile czas po temu,
Tak uprzejmej prośbie twej i żądaniu twemu.
Zdrów bądź, a wiersz ten do mnie auzoński posłany,
Racz przyjąć w jakąkolwiek polszczyznę przybrany ${ }^{13}$.

Które utwory spośród opublikowanych w zbiorku Cudowne wiersze Maciejowski przesłał Grochowskiemu z prośbą o ich spolszczenie - pozostaje kwestią otwarta. Były to zapewne wspomniane w dedykacji wiersze lacińskie (auzońskie): bez wątpienia pieśń „Pater en noster, genitor noster...”, niewykluczone, iż także lament Panny Najświętszej „Ah, mater, iam non mater...”. Trzeci wiersz takiejże materyjej (,Wszyscy mieszkańcy domu niebieskiego...”) to przypuszczalnie autorski utwór Grochowskiego, przez niego również przetłumaczony, a właściwie zwięźle sparafrazowany jako „tekst łaciński tegoż sensu”, albo - co mniej prawdopodobne - pieśń pochodząca $z$ któregoś $\mathrm{z}$ ówczesnych kancjonałów i tylko przełożona przez poetę na łacinę ${ }^{14}$. Pięć kolejnych wierszy to cykl przeniesiony z druku Hierozolimska

M e j o r, op. cit., s. 374. Wiersz „Pater en noster, genitor noster...” mógł Maciejowski znaleźć również w dziele Delle relationi universali di Giovanni Botero Benese. Quarta parte (Brescia 1596, s. 67).

Groch ow ski, Cudowne wiersze [...], s. 2.

14 Według J. Surzyń skie go (dodatek do „Muzyki Kościelnej” z 1885 r.; Śpiewnik kościelny polski. „Muzyka Kościelna” 1886, nr 5, s. 36) pieśń „Wszyscy mieszkańcy domu niebieskiego...” znajdowała się w trudnym dziś do zidentyfikowania kancjonale klarysek gnieźnieńskich z początku XVII wieku. Rejestruje ją rękopiśmienny kancjonał benedyktynek staniąteckich z 1701 roku (obecnie w Bibl. Diecezjalnej w Sandomierzu). Utwór opublikował J. S u r zy ń s ki m.in. w Śpiewniku kościelnym dla użytku parafii rzymsko-katolickich (cz. 2. Poznań 1886, s. 184-185), później 
procesyja w kościele chwalebnego Grobu Pana Jezusowego zwyczajna [...], po raz pierwszy wydanego w roku $1607^{15}$; w Cudownych wierszach opatrzono go tytułem Żałosne niewiasty albo narzekalnice żydowskie nad Panem Jezusem, krzyż swój dźwigajacym na górę Kalwaryja, o których świadczy ewanjelija. Podobnie wiersz Serdeczne narzekanie przy grobie Pańskim błogosławionej Maryjej Magdaleny został przeniesiony z Hierozolimskiej procesyi, gdzie figuruje jako Rozmyślanie jedenaste ${ }^{16}$. Zbiorek zamyka wierszowana Porankowa $i$ wieczorna do skruchy zaprawa na kształt modlitwy, o incipicie „Jezu mój, o prawdziwy Boże i człowieku".

Cały zatem tomik Cudownych wierszy ma charakter wybitnie pasyjny: zebrane w nim utwory przynoszą poetycką medytację tajemnicy Męki Pańskiej, współcierpienia i współodczuwania z Jezusem jego Matki, „wszystkich mieszkańców nieba”, Marii Magdaleny, niewiast towarzyszących skazańcowi w drodze na Kalwarię, wreszcie - każdego pobożnego chrześcijanina. Jest odpowiedzią starego księdza-poety nie tylko na prośbę Kaspra Maciejowskiego, ale i na katechetyczno-pastoralne potrzeby potrydenckiej formacji religijnej, na potrzeby ówczesnego Kościoła, który, jak czytamy w wierszu dedykacyjnym, „Uważa Męki Pańskiej drogie tajemnice, / Tak, iż ni o czym inszym brzmią wiernych świątnice".

W dotychczasowym przeglądzie zawartości Cudownych wierszy najmniej uwagi poświęciłem zamieszczonej na stronicach 5-8 zbiorku Drugiej żałobie Panny Naświętszej [...], podczas gdy to właśnie ten utwór jest ,jeszcze jednym przyczynkiem do recepcji twórczości Sannazara w literaturze staropolskiej”. Należy on do niezwykle popularnego w późnym średniowieczu, potem również w okresie potrydenckim, gatunku lamentów (żalów, planktów) Matki Boskiej; u nas, jak wiadomo, najstarszym i najcenniejszym zabytkiem $z$ tego kręgu jest XV-wieczny Lament świętokrzyski ${ }^{17}$. I - co tutaj najważniejsze - Druga żałoba Panny Naświętszej [...] to parafrazowany przekład fragmentu księgi pierwszej De partu Virginis Sannazara ${ }^{18}$, fragmentu, w którym król Dawid, oczekujący w otchłani na przyjście Zbawiciela,

zaś m.in. wydawcy monografii Polskie pieśni pasyjne. Średniowiecze i wiek XVI (Red. J. Nowak-Dłużewski. T. 1: Teksty i komentarze. Warszawa 1977, s. 347-348); w obu edycjach zamieszczono jednak wersję liczącą 10 zwrotek, podczas gdy w Cudownych wierszach pieśń ma ich 16).

15 S. G r o c h ow s k i, Lamenty niektórych białych głów jerozolimskich nad Panem Jezusem krzyż swój dźwigajacym na górę Golgotę. W: Hierozolimska procesyja $w$ kościele chwalebnego Grobu Pana Jezusowego zwyczajna [...], wzięta z ksiag Hierozolimskiej peregrynacyjej albo pielgrzymowania Jaśnie Wielmożnego Pana Mikołaja Chrzysztofa, na Ołyce i Nieświeżu ksiażęcia etc., etc., $k$ woli nabożym ludziom, a mianowicie bractwom Kompasyjej Zbawiciela naszego i procesyjom ich, przez ks. Stanisława Grochowskiego, kustosza kruszwickiego z łacińskiego tekstu przełożona. Kraków 1607.

16 S. Grochowski, Rozmyślanie jedenaste. W: jw.

17 Zob. m.in. S. Graci ot ti, „Lament świętokrzyski” a średniowieczna tradycja „Planctus Beatae Mariae Virginis”. W zb.: Od „Lamentu świętokrzyskiego” do „Adona”. Włoskie studia o literaturze staropolskiej. Red. G. Brogi Bercoff, T. Michałowska. Warszawa 1995. - P. Stępień, Chaos $i$ ład. Lament świętokrzyski. W: $Z$ literatury religijnej polskiego średniowiecza. Warszawa 2003. - R. Mazurkiewicz, Stabat mater dolorosa. W: Z dawnej literatury maryjnej. Zarysy i zbliżenia. Kraków 2011.

18 Na źródło łacińskiego wiersza, będącego podstawą przekładu Grochowskiego, zwrócił mi uwagę w korespondencji mejlowej Christophe Vielle, orientalista z uniwersytetu w Louvain, który przy innej okazji zainteresował się „pseudo-indyjskością” Cudownych wierszy Grochowskiego. Zob. 
ukazuje w prorockiej wizji przyszłą mękę Chrystusa i cierpienie jego matki. Grochowski poprzedził swój przekład incipitem oryginału, następnie zamieścił jego tekst w całości $z$ tytułem Też wiersze po łacinie ${ }^{19}$.

DRUGA ŻAŁOBA PANNY NAŚWIĘTSZEJ,

która jedno pacholę włoskiego narodu, wierszem łacińskiem napisawszy, oddał w Rzymie papieżowi Adryjanowi

„Ah mater, iam non mater, sed flentis et orbae Infelix simulacrum et functi corporis umbra".

Ach, matko, już nie matko, lecz rzekę prawdziwiej,

Znikomy cieniu matki, jakby już nieżywej!

Przed krzyżem stoi smutna, rumianą skrwawiwszy

Twarz swoję, a stargane włosy rozpuściwszy,

5

Oblewa płaczem piersi, patrząc już na one

Gwiazdom podobne oczy synowskie zamknione.

Okrutną zowie ziemię i słońce okrutne,

Nie mniej siebie, że patrzy na rzeczy tak smutne.

10

Raz i drugi powtarza rzecz jednemi słowy,

A odźwięk się otrąca po górach z jej mowy,

Od którego się zdało jakby głuche skały

Wespół z matką strapioną syna jej płakały.

Na ostatek, wzdychajac, pod krzyż przystępuje,

Twarde drzewo obłapia i z płaczem całuje.

„Ach - ciemnie mówi głosem - kto mię z mej zacności

I z miejsca spokojnego w takie nawałności

Dziś przywiódł, Synu drogi, ojcowskie kochanie,

Ale teraz mój smutku i ciężkie wzdychanie?

20

Kto mi cię wziął z opieki? Od czyjej zazdrości

Wydanyś na taka śmierć pełną okrutności?

Czyja niezbożna ręka tak wszeteczna beła,

Że twą nawdzięczniejszą twarz krwią tak oszpecieła?

Kto prawo, kto przywilej ma na ziemi taki,

Że Bogu despekt czyni tak nie lada jaki?

Na to żem cię, uboga matka, wychowała,

Abym na twe haniebne zeście dziś patrzała?

Tyżeś on mój kochany? A tyżeś to ona

Ma jedyna pociecha, tą śmiercią zgładzona?

Tyś jest, po którym sobie tom obiecowała,

Że okrom mnie szczęśliwsza matka być nie miała?

Tak-że mię już odchodzisz, tak mię rozdzieli-li

Ten lud $z$ toba, by na me sieroctwo patrzyli?

Ach, Synu, tyś niedawno oddał umarłego

Brata siostrom, kilka dni w grobie leżącego.

35

Często cię lamentliwe matki upraszały

Za umarłe dziatki swe, by z nich żywe miały.

A ja tu do czyjego skłonię prośbę ucha

Ch. Vi elle, Bhagavadgìtà à Copacabana S. I.: littérature dévotionnelle traduite de la langue „indienne" au XVIe siècle (w druku).

19 W Rytmach [...] Czaradzkiego (w. 279-280) przełożone zostały jedynie cztery pierwsze wersy tego fragmentu: „A matka już nie matka, ale cień bez władzy, / Pod krzyżem płakać będzie syna swego stradzy". 
Za synem i Bogiem swym? Kto mię dziś wysłucha? Komu się będę skarżyć? Okrutni katowie,

Gdyżeście niewinnemu gwałtem wzięli zdrowie,

Czemu też mnie, jeśli co miłosierdzia macie,

Pospołu z synem tejże śmierci nie zadacie?

Na mię, ja tego pragnę, wylejcie gniew, na mię

Swą zapalczywość, włóżcie drugi krzyż na ramię, A ja go na tę górę ochotnie poniosę,

Tylko niechaj przy synie umrę na nim, proszę.

Próżno mówię do tego okrutnego gminu,

Lecz ty, władogromego Boga i mój Synu,

Użal się mnie, matki swej, weź z sobą pod ziemię,

Do otchłani piekielnych, miedzy zmarłych cienie.

Pozwól mi, niech też patrzę, gdy spiżane progi

Piekielne będziesz łamał i tameczne wrogi

$Z$ ich mocą będziesz kruszył, a stamtąd potężnie

Wyrwiesz i wyprowadzisz zatrzymane więźnie.

Niech mi sie godzi, matce, otrzeć z synowskiego

Czoła pot, piękną pracą w ten czas strudzonego" 20 .

\section{TEŻ WIERSZE PO ŁACINIE}

Ah mater, iam non mater, sed flentis et orbae Infelix simulacrum et functi corporis umbra. Ante crucem discissa genas, laniata capillum, Stat lacrimans tristique irrorat pectora fletu. Inspectansque sui demum morientia nati Lumina, crudeles terras, crudelia dicit Sidera, crudelem se se, quod talia cernat Vulnera, saepe vocat; tum luctisono ululatu Cuncta replens, singultatim sic ingemit ore, Ingemit et duro figit simul oscula ligno.

„Heu, quis me miseram - exclamat - quis culmine tanto Deiectam subitis involvit, nate, procellis?

Nate, Patris virtus, sanguis meus, unde repente Haec fera tempestas? Quis te mihi livor ademit? Quae manus indigno foedavit sanguine vultus? Cui tantum in superos licuit? Bella impia caelo Quis movet? Hunc ego te post tot male cauta labores Aspicio? Tune illa tuae lux unica matris? Tu ne animae pax et requies spesque ultima nostrae Sic raperis? Sic me solam exanimemque relinquis? $O$ dolor, extincto iam te pro fratre sorores, Pro natis toties exoravere parentes. Ast ego pro nato, pro te, Dominoque Deoque, Guem misera exorem? Quo tristia pectora vertam? Cui querar? O me, me dirae, me perdite dextrae, Me potius, si qua est pietas, immanibus armis Obruite, in me omnes consumite pectoris iras! Vel tu, si tanti est hominum genus, eripe matrem, Quae rogat et Stygias tecum duc, nate, sub umbras. Ipsa ego te per dura locorum inamoenaque vivis Regna sequar: liceat frangentem cernere portas 
Aeratas, liceat pulchro sudore madentem

Eversorem Erebi materna extergere dextra"21.

Już pobieżne zestawienie obu tekstów (oryginał liczy 33 wersy, przekład - 56) dowodzi, że Grochowski nie ograniczył się do literalnego spolszczenia lamentu Maryi z De partu Virginis ${ }^{22}$; jego „naśladowanie” ma charakter parafrazy emulacyjnej. Autor Cudownych wierszy nie tylko zastępuje antyczno-renesansowe figury Styksu i Erebu obrazem otchłani piekielnych (choć, z drugiej strony, wprowadza nie występujący w oryginale, a odnoszacy się do Boga epitet „władogromy”), ale ingeruje również w samą materię poetyckiego obrazowania, np. motyw „okrutnych gwiazd” (,crudelia sidera”), obojętnie patrzących na umierającego Syna Bożego, redefiniuje i waloryzuje całkiem inaczej niż oryginał: „Gwiazdom podobne oczy synowskie zamknione”. Autorską interpolacją Grochowskiego są m.in. wersy 9-12, niektóre motywy zostają w polskim przekładzie peryfrastycznie rozwinięte, np. pytanie „Quis te mihi fluctus ademit? [Cóż to za fala mi cię zabiera?]” zyskuje postać: „Kto mi cię wziął z opieki? Od czyjej zazdrości / Wydanyś na taką śmierć pełną okrutności?”; podobnie potraktował tłumacz motyw wskrzeszenia Łazarza i zmarłych dzieci.

Jako osobna kompozycja planctus Mariae Sannazara zachował się w kilku różnych kodeksach rękopiśmiennych ${ }^{23}$, a po wydaniu De partu Virginis w 1526 roku był cytowany również jako samodzielny utwór w kazaniach i medytacjach pasyjnych, m.in. w zbiorach kazań Johannesa Ecka czy Ludwika z Granady. Z podobną sytuacją mamy do czynienia w Cudownych wierszach. Porównanie zamieszczonego tu łacińskiego lamentu z „kanoniczną” jego wersją w De partu Virginis ${ }^{24}$ przekonuje, iż Grochowski dysponował odpisem reprezentującym nieco inny wariant tego utworu. Jeszcze bardziej frapująca (podobnie jak w przypadku wspomnianego wcześniej wiersza Bencjusza) jest dodana do tytułu przez polskiego poetę-tłumacza informacja o napisaniu i ofiarowaniu łacińskiego lamentu papieżowi Hadrianowi VI przez ,jedno pacholę włoskiego narodu”.

Hadrian VI na tronie papieskim zasiadał od stycznia 1522 do września 1523, gdy liczący wówczas 65 lat Sannazaro „pacholęciem” z pewnością już nie był. Wiadomo, że na wiosnę 1521 wysłał on z Neapolu do Rzymu kopię De partu Virginis, poddając poemat osądowi przyjaciół i polecając go życzliwej uwadze papieża Leona X, który wprawdzie zachęcił poetę do ogłoszenia dzieła drukiem, sam jednak jego publikacji nie doczekał, gdyż zmarł 1 grudnia 1521. Rękopiśmienną kopię planktu z De partu Virginis mógł zatem przekazać jego następcy, Hadrianowi VI, jakiś bliżej nie znany młodzieniec między końcem sierpnia 1522 (dopiero wtedy nowo wybrany papież przybył do Rzymu z Hiszpanii) a wrześniem 1523. Przypuszczenie takie

\section{Ibidem, s.
M. Plezi.}

22 Sinapis. Essays on Neo-Latin Literature in Honour of Jozef IJsewijn. Ed. G. T o u r n o y, D. S a c r e. Leuven 1997, s. 246, przypis 25.

24 Zob. np. Czaradzki, op. cit., s. 72, 109 (tutaj tekst De partu Virginis za wyd. z 1607 roku). J. Sannazaro, De partu Virginis. Ed. Ch. Fantazzi, A. Peros a. Firenze 1988. 
sformułował wybitny znawca twórczości autora Arkadii, Allesandro Perosa, odkrywca i badacz zachowanego w paryskiej Bibliothéque Mazarine kodeksu, w którym zapisano m.in. planctus Mariae Sannazara, opatrzony, jak stwierdził uczony, „dziwacznym tytułem": Carmen super planctum Mariae Virginis, quod puer Italus Adriano pontifici obtulit ${ }^{25}$.

Mielibyśmy zatem cenną wskazówkę, przynajmniej częściowo rozjaśniająca pochodzenie wzmianki Grochowskiego o „pacholęciu włoskiego narodu”. Częściowo, bo trudno przypuszczać, by poeta otrzymał od Maciejowskiego akurat kopię paryskiego przekazu Sannazarowego lamentu. Okazuje się jednak, że dość łatwo można odnaleźć bardziej prawdopodobne źródło, powszechnie w czasach Maciejowskiego i Grochowskiego dostępne - wielokrotnie w XVI stuleciu wydawane kazania wspomnianego już Jana Ecka (właściwie: Johannes Maier), katolickiego teologa i polemisty kontrreformacyjnego, od roku 1520 nuncjusza papieskiego. W roku 1533 w Augsburgu ukazał się zbiór jego kazań pt. Quinta pars operum Iohannis Eckii contra Lutherum et alios declamatoria, później często wznawiany pod rozmaitymi tytułami ${ }^{26}$. Już w tym pierwszym wydaniu zamieszczony został, w rozważaniu męki i śmierci Jezusa (Quomodo in cruce mortuus Dominus), tekst Sannazarowego lamentu Maryi, poprzedzony informacja: „Lubet hic super planctu Mariae carmen ascribere, quod puer Italus Adriano pontifici obtulit, et secretarius huius Hetzius mihi illius copiam fecit [Niech mi będzie wolno dodać tu pieśń o lamencie Maryi, która pewien italski chłopiec podarował papieżowi Adrianowi, a jej kopię sporządził dla mnie sekretarz papieski Hetzius]"27. Wspomniany tu Dietrich Hetzius to flamandzki sekretarz Hadriana VI, który po śmierci papieża wywiózł wszystkie regesta do Liège, a później odmówił ich oddania Klemensowi VII, następcy Hadriana na tronie papieskim $^{28}$. Zapewne między rokiem 1523 a 1533 przekazał odpis planktu z De partu Virginis Eckowi, ten zaś wykorzystał go w swoich homiliach pasyjnych.

Zarówno w kodeksie paryskim, jak i w licznych wydaniach kazań Jana Ecka nota poprzedzająca lament Matki Boskiej mówi jedynie o ofiarowaniu go papieżowi Hadrianowi przez jakiegoś młodzieńca, tymczasem Grochowski przypisał owemu „pacholęciu włoskiego narodu” również autorstwo wiersza. Mało prawdopodobne, by ów naddatek mógł starczyć za dowód, że nasz poeta był świadom pochodzenia pierwowzoru Drugiej żałoby Panny Naświętszej, bez wątpienia jednak urzekło go jego piękno i autentyzm, skoro umieścił swój utwór zaraz po cudownej, „nie ręką ludzką uczynionej” pieśni o Męce Pańskiej z Kapakabano.

A. P e r o s a, Un codice parigino del „Planctus Virginis” del Sannazaro. W: Studi di filologia umanistica. T. 3: Umanesimo italiano. A cura di P. Viti. Roma 2000, s. 309. rum 1533, następnie: Homiliarius contra sectas, ab ipso autore denuo recognitus, Ingolstadt 1536; późniejsze wydania ukazywały się m.in. w Paryżu (1538, 1549, 1574, 1594) i w Kolonii (1555). Quinta pars operum Iohannis Eckii [...]. fol. CLIII; Homiliarius contra sectas [...], k. 118v. 
Abstract

ROMAN MAZURKIEWICZ Pedagogical University, Cracow

ORCID 0000-0002-2972-8922

\section{ANOTHER CONTRIBUTION TO SANNAZARO'S CREATIVITY RECEPTION IN OLD POLISH LITERATURE}

The author of the article examines the sources and the circumstances of producing a collection of Passion pieces by Stanisław Grochowski entitled Cudowne wiersze $z$ indyjskiego języka przełożone [...] (Wonderful Verses from the Indian Language, 1611), and especially Druga żałoba Panny Naświętszej (Holy Mary's Second Mourning) contained in it. The poem turns out to be a paraphrased translation of a fragment De partu Virginis by Jacopo Sannazaro presenting in King David's prophetic vision the future torment of Christ and the suffering of his mother. Sannazaro's Planctus Mariae survived as a separate composition in a few handwritten codices and was also quoted as an independent piece in old preachments and meditations about the Passion. An analysis of Grochowski's poem proves that the Polish poet used this kind of account-the view is also supported by a comparative analysis as well as by the information added to the title of the poem about offering it to Pope Adrian VI. 